\title{
Towards a national security psychology in the South African National Defence Force
}

\begin{tabular}{|c|c|}
\hline \multicolumn{2}{|c|}{$\begin{array}{l}\text { Book Title: } \\
\text { Psychology in the Service of } \\
\text { National Security }\end{array}$} \\
\hline \multicolumn{2}{|l|}{ Book Cover: } \\
\hline $\begin{array}{l}\text { Psychology in } t \\
\text { Service of } \\
\text { National Securi }\end{array}$ & \\
\hline \multicolumn{2}{|c|}{ A. David Mangelsdorff } \\
\hline \multicolumn{2}{|c|}{$\begin{array}{l}\text { Editor: } \\
\text { A. David Mangelsdorf }\end{array}$} \\
\hline \multicolumn{2}{|l|}{$\begin{array}{l}\text { ISBN: } \\
1-59147-355-1\end{array}$} \\
\hline \multicolumn{2}{|c|}{$\begin{array}{l}\text { Publisher: } \\
\text { American Psychological } \\
\text { Association, Washington } \\
\text { D.C., } 338 \text { pp., ZAR695.00* } \\
\text { *Book price at time of review }\end{array}$} \\
\hline \multicolumn{2}{|c|}{$\begin{array}{l}\text { Towards a national security } \\
\text { psychology in the South } \\
\text { African National Defence Force }\end{array}$} \\
\hline \multicolumn{2}{|l|}{$\begin{array}{l}\text { Reviewer: } \\
\text { Jarred Martin }{ }^{1}\end{array}$} \\
\hline \multicolumn{2}{|c|}{$\begin{array}{l}{ }^{1} \text { Department of Psychology, } \\
\text { Institute of Maritime } \\
\text { Medicine, South African } \\
\text { National Defence Force, } \\
\text { South Africa }\end{array}$} \\
\hline \multicolumn{2}{|c|}{$\begin{array}{l}\text { Email: } \\
\text { jmukzn@gmail.com }\end{array}$} \\
\hline \multicolumn{2}{|c|}{$\begin{array}{l}\text { Postal address: } \\
212 \text { Hiddingh Village, } \\
\text { Hiddingh Avenue, Gardens, } \\
\text { Cape Town } 8001 \text {, } \\
\text { South Africa }\end{array}$} \\
\hline \multicolumn{2}{|c|}{$\begin{array}{l}\text { How to cite this book review: } \\
\text { Martin, J. (2014). Towards a } \\
\text { national security psychology } \\
\text { in the South African } \\
\text { National Defence Force. } \\
\text { SA Journal of Industrial } \\
\text { Psychology/SA Tydskrif vir } \\
\text { Bedryfsielkunde, } 40 \text { (2), Art. } \\
\# 1206,3 \text { pages. http:// } \\
\text { dx.doi.org/10.4102/sajip. } \\
\text { v40i2.1206 }\end{array}$} \\
\hline \multicolumn{2}{|l|}{ Read online: } \\
\hline 口ifra & $\begin{array}{l}\text { Scan this QR } \\
\text { code with your } \\
\text { smart phone or } \\
\text { mobile device } \\
\text { to read online. }\end{array}$ \\
\hline
\end{tabular}

\section{Introduction}

In 2015, the allied fields of organisational, research and (neuro-)clinical psychology, which together constitute the backbone of military and operational psychology in the South African National Defence Force (SANDF), will mark an ominous centenary: 100 years since shell shock was first identified. Charles S. Myers (1915), a psychologist in the British Royal Army Medical Corps during World War I, was the first to use the term shell shock as a means of recognising a diffuse collective of neuropsychological symptoms which resulted in soldiers being unable to function on the battlefield. What continues to make Myers's contribution resonate to this day, despite the relegation of shell shock to the nosological trashcan, is his recognition of the effects of war and trauma on the mental health of military personnel long after they have returned home from the frontlines.

Since 1918, there has been a longstanding appreciation of the interventions psychological professionals can offer as a strategy to preventing and treating mental-health difficulties amongst combat-active military personnel (Yerkes, 1918). In recent years, however, the field of mental health care and its application within the environment of national security, more broadly, and the military, more specifically, have come under acute scrutiny. Internationally, psychological and behavioural scientists working in the armed forces have been implicated in ethically questionable practices (Davis, Gribble, Kerman \& Muskat, 2011). Closer to home, the Health Professions Council of South Africa (HPCSA) has brought to light the ethically questionable activities of some health professionals' conduct within the former South African Defence Force (SADF) (HPCSA, 2014). South African psychologists have not been immune from speculation concerning their complicity in the detainment of political prisoners during apartheid (Naidoo, 2009).

In response to these developments in military psychology, a recent wave of texts by scientists and practitioners of mental health care in the military in the United States of America (USA) have specifically sought to address the desperate need for empirically supported treatment modalities and ethical organisational-occupational treatment in the military. Military psychologists, whether clinically or organisationally oriented, working within the national security complex of the SANDF are now coming under increasing pressure to: (1) develop an intimate awareness of the mentalhealth needs and occupational stressors that military service pose for deployed and embedded personnel in the theatre of operations that is the African continent (Martin, Van Wijk, Makhaba \& Hans-Arendse, 2013) and (2) demonstrate transparency and sensitivity to the ethical dilemmas which are unique and commonplace to rendering specialist psy-knowledge in the South African national security environment (Martin, 2013). Psychology in the Service of National Security (PSNS) is one such text that emerges in this milieu and endeavours to further contribute to this everincreasing body of scholarship on mental health in the military.

\section{Outline of the text}

PSNS provides readers with a primer to the application of psychological theory, research and interventions within the national security environment. In this regard, PSNS falls under the broader base of literature contributing towards the field of operational psychology. From the outset, PSNS highlights that:

... the meaning of national security has changed from threat of war and invasion by other nation states to a much broader definition that also includes community response to natural disasters, technological failures, domestic disturbances, and terrorism (domestic and transnational) (p. 3, emphasis original).

It is within this context that military psychologists are findings themselves in new roles in clinical practice as well as in operations, policymaking, organisational development, psychodiagnostic assessment and research.

Note: The views expressed here are those of the author and should not be considered to reflect the official policy or position of the South African National Defence Force, the Department of Defence or the South African Government.

Copyright: (C 2014. The Authors. Licensee: OpenJournals Publishing. This work is licensed under the Creative Commons Attribution License. 
Running throughout the text is an orientation towards occupational health. This perspective underwrites the empirical impetus of the text and conceptually organises it in three ways. The first of these is the need for mentalhealth interventions and policies in the military to be rooted in evidenced-based treatment modalities and data. This includes the need of psychological interventions to accommodate changes in the nature of warfare, the evolving roles of military personnel, the changing geographies and tempo of operational deployment and the increasing prevalence of traumatic-stress reactions in combat-active military personnel. Secondly, the interventions designed by mental-health practitioners in the military would benefit from an enhanced degree of service-specificity. For example, the subaquatic operational environments of naval submariners are markedly different from conventional landward operations of the army and, therefore, require very different psychological and neuropsychiatric assessment needs and intervention possibilities. Lastly, PSNS outlines the growing importance of preventative mental health care interventions in combatting the incidence of mental illness and 'psycausalities' in the theatre of operations. In particular, PSNS places varying emphases on resilience-building strategies (which are imbricated into policy, organisational culture, mental-health screening and clinical interventions), adaptive coping mechanisms and positive psychology.

Although PSNS delimits the focus of its content to nationalsecurity psychology, it carries links and connections to multi-disciplinary mental-health care in the military. On the one hand, the text works as a useful clinical compendium for mental health care practitioners, such as psychologists, counsellors and social workers. On the other hand, the text compiles a vast array of peer-reviewed and empirically supported research and contemporary data for applied social science, health-care researchers and policy developers.

\section{Structure, style and content of the text}

After a brief introduction penned by the editor, A. David Mangelsdorff, the text is subsequently partitioned into five sections and a conclusion. Each section of PSNS covers distinct areas of research and practice in contemporary national-security psychology. Each section is sub-divided into chapters written by notable mental-health and behavioural-science specialists in the military who deal with specific topics of interest in each chapter.

The first section of the text is entitled 'From military psychology to national security psychology'. Topics included in this section include the changing face of national security (chapter 1) and a primer to the foundations of national-security psychology (chapter 2). I would particularly recommend chapters 1 and 2 as must-reads. Chapter 1 contextualises the evolving nature of the military and national security. This should have interesting resonance with South African military psychologists given recent changes to the national landscape concerning security legislation. This is followed by chapter 2 which introduces how key areas of mental-health scholarship plug into the different agencies and structures of the national security complex; and how psychologists can help to preserve and reform the military whilst maintaining the emotional wellbeing of military personnel.

The second section of the text tackles the field of individual differences and human-factors engineering. The topics covered in this section are primarily concerned with how the wide range of intellectual, emotional and physical aptitudes of individuals entering and working in the military can be engineered and accommodated to maximise operational efficiency. Each of the chapters outlines the necessity to execute human-factors research and how this data has and can been integrated in the national-security complex to preserve the psychological fitness of military members when operationally active. Data included here directly speaks to the interests of research and organisational psychologists at the South African Military Psychological Institute (MPI). Topics included in this section are the following: human factors research in the USA naval service (chapter 3), the national security interests within USA naval health research (chapter 4) and USA army research into human performance (chapter 5).

In the third section of PSNS, personnel and organisational management, that is, 'the assessment, selection, classification, assignments, and training and education of personnel' (p. 97), comes under focus. Topics include research and development related to national-security concerns for the military (chapter 7), the application of psychology in airforce selection, assignment, training and education (chapter 8) and USA naval-personnel research and development (chapter 9). I would recommend this section for South African organisational psychologists involved in aspects of specialist assessment or selection in the military.

The fourth section of text deals with the development of clinical psychology and counselling applications. Subtopics covered throughout the chapters in this section include the application of clinical psychology to policymaking, research and development, safety, operational readiness planning, special operations, teaching and command in the military. Each of these is unpacked with their relevance to the three major arms of military service: navy (chapter 10), army (chapter 11) and air force (chapter 12). Chapter 10 will be of specific interest to all mental-health professionals because of the special attention to data and interventions related to Posttraumatic Stress Disorder (PTSD).

The penultimate section of the text takes an interesting turn into the area of applied social psychology in the military. It is rare for texts on military psychology to touch on issues of social psychology, let alone dedicate an entire four chapters to it. The topics in this chapter include the USA Army Research Institute and its work into behavioural and social sciences (chapter 13), racial integration and race relations in the USA Armed forces (chapter 14), psychological research with military women (chapter 15) and military family research (chapter 16). Given the historical legacy of apartheid, 
racialised discrimination and gender inequality in South Africa, the content in chapters 14 and 15 will be of greatest interest to South African military psychologists - particularly because clinical and organisational psychologists were at the coal face of operations to integrate the former liberation movements and SADF during the early 1990s.

The concluding section of the text, chapter 17, provides a critical reflection on psychology's strategic position for contemporary national-security concerns.

Stylistically, each chapter is relatively formulaic, and the text can be read with comfort by those who are initiated into the fields of national security and mental health care as well as those who are not. This particular feature of the text is refreshing since many of its kind tend to become bogged down in jargonised military-speak. Although PSNS is based primarily on data generated from the USA national-security landscape, I consider it an imperative read for psychological practitioners and scientists in the SANDF because it critically engages the most recent military research and operational data. The text not only yields clinical, organisational and policy interventions to preserve the psycho-emotional wellbeing of military personnel but, also, provides incisive comment on organisational strategies and clinico-therapies to treat common operational mental-health difficulties such as adjustments disorders and PTSD.

\section{Conclusion}

On the 23rd of March 2013, skirmishes in the Central African Republic (CAR) between the Seleka rebel militia and troops of the SANDF left 27 South African soldiers wounded and, to date, 14 dead. The troop losses sustained in CAR, the significant involvement of SANDF military personnel in the new United Nations Force Intervention Brigade in the Democratic Republic of the Congo (DRC) and the changing mandate of South African forces from peace-keeping to peaceenforcement in the DRC all serve to reiterate South Africa's military presence in peace-support operations throughout the African continent. These developments within South Africa's national security landscape point to an increased operational tempo for troops, a greater likelihood of exposure to trauma as well as prolonged deployment periods away from home (in excess of 12 months). Under these conditions, the role played by psychologists in the SANDF will become increasingly crucial in rendering sciencebased and ethically grounded mental-health services and organisational interventions in a uniquely African military. PSNS supplements this need by providing an adaptive psyknowledge base which meets the changing mental-health needs of active-duty military personnel.

\section{References}

Davis, M., Gribble, J., Kerman, T., \& Muskat, H. (Producers). (2011). Doctors of the dark side [Documentary]. Retrieved February 28, 2012, from http://www. doctorsofthedarkside.com

Health Professions Council of South Africa. (2014). Dr Wouter Basson found guilty of unprofessional conduct. Retrieved February 14, 2014, from http://www.hpcsablogs.co.za/dr-wouter-basson-found-guilty-of-unprofessional-conduct/

Martin, J. (2013). Ethical practice in South African operational psychology: A review of trends for psychologists in the SANDF. Paper presented at the South African Military Health Service Academic \& Research Conference, Pretoria, South Africa.

Martin, J., Van Wijk, C.H., Makhaba, L. \& Hans-Arendse, C. (2013). Missing in action: The significance of bodies in African bereavement rituals. Psychology in Society, 44(1), 42-63.

Myers, C.S. (1915). A contribution to the study of shell shock: Being an account of three cases of loss of memory, vision, smell, and taste, admitted into the Duchess of Westminster's war hospital, Le Touquet. The Lancet, 185(4772), 316-320. http://dx.doi.org/10.1016/S0140-6736(00)52916-X

Naidoo, R. (2009). The fourth dimension: The untold story of military health in South Africa. Pretoria, South Africa: South African Military Health Service.

Yerkes, R.M. (1918). Psychology in relation to the war. Psychological Review, 25, 85115. http://dx.doi.org/10.1037/h0069904 